\title{
Outcome of pregnancy after renal transplantation
}

International Journal of Women's Health

\author{
Sarah Mohamed Hassan \\ Radwa Fahmy \\ Eman Fawzy Omran \\ Eman Aly Hussein \\ Wafaa Ramadan \\ Dalia Farouk Abdelazim \\ Obstetrics and Gynecology \\ Department, Cairo University, \\ Cairo, Egypt
}

Aim: The aim of our study was to compare the outcome of pregnancy in patients who became pregnant within 24 months of renal transplantation and patients who became pregnant more than 24 months after renal transplantation.

Materials and methods: The sample population of our prospective cohort study comprised of 44 patients who became pregnant following renal transplantation. In all cases, living donors were used for renal transplantation. The patients were allocated into either group A, which included 24 patients who became pregnant more than 24 months after renal transplantation, or group B, which included 20 patients who inadvertently became pregnant within 24 months of renal transplantation. Serum creatinine and 24 -hour urinary protein concentration were measured each trimester. The incidences of preeclampsia and gestational diabetes, the timing and mode of delivery, the rate of preterm labor, and the mean fetal birth weight were determined.

Results: The mean gestational ages in groups A and B were $35.8 \pm 3$ weeks and $34.1 \pm 2.5$

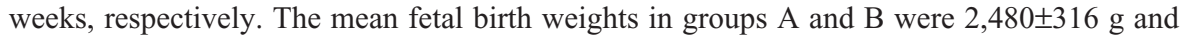
$2,284.5 \pm 262 \mathrm{~g}$, respectively. These differences were statistically significant. The incidence of preterm labor was $45.8 \%$ in group A and $55 \%$ in group B. Proteinuria was significantly higher in group B during the third trimester of pregnancy. Preeclampsia occurred in $25 \%$ of the cases in group A and $30 \%$ of the cases in group B; this difference was not statistically significant. Gestational diabetes occurred in 2 out of 24 cases in group A and 2 out of 20 cases in group B. For group A and group B, normal vaginal delivery occurred in 58.3\% and 55\% of cases, respectively, and cesarean section was performed in $41.6 \%$ and $45 \%$ of cases, respectively.

Conclusion: A longer interval between renal transplantation and pregnancy is associated with better pregnancy outcome.

Keywords: pregnancy, renal transplantation, time interval

\section{Introduction}

Renal transplantation has not only improved the survival of patients with end-stage renal disease but also provided such patients with an opportunity to restore their fertility potential. ${ }^{1,2}$

Ever since the first reported successful pregnancy in a recipient of a kidney transplant occurred in 1958, hundreds of successful pregnancies of this type have been reported. ${ }^{3,4}$ Generally, the optimal timing of pregnancy in these individuals is at least 2 years after successful transplantation. ${ }^{5}$ However, the restoration of fertility is less common in women close to the end of their childbearing period. Therefore, recommendations regarding the time interval between transplant and pregnancy might be liberalized in specific situations, and the 2009 guidelines of the Kidney Disease: Improving Global Outcomes condone pregnancy one year after renal transplantation in cases involving stable renal function (creatinine clearance $>40 \mathrm{~mL} / \mathrm{min}$ ), proteinuria $<1 \mathrm{~g} / \mathrm{d}$, and the cessation of teratogenic drugs. ${ }^{6}$ According to a consensus opinion of the American Society of Transplantation, pregnancy is permissible if graft
Correspondence: Sarah Mohamed Hassan Obstetrics and Gynecology Department, Kasr AIAini Hospital, Kasr Alainy Street, Garden City, Cairo, PO Box II 562, Egypt Tel +201003733671

Fax +20 223682035

Email saramohamed7880@yahoo.com
International Journal of Women's Health 2018:10 65-68

65

Dovepress f in 0

http://dx.doi.org// 0.21 477/IJWH.S148386 (c) (i) (5) 2018 Mohamed Hassan et al. This work is published and licensed by Dove Medical Press Limited. The full terms of this license are available at https://www.dovepress.com/terms.php (c) $\mathrm{BY}$ and incorporate the Creative Commons Attribution - Non Commercial (unported, v3.0) License (http://creativecommons.org/licenses/by-nd/3.0/). By accessing the work you hereby accept the Terms. Non-commercial uses of the work are permitted without any further permission from Dove Medical Press Limited, provided the work is properly attributed. For permission for commercial use of this work, please see paragraphs 4.2 and 5 of our Terms (https://www.dovepress.com/terms.php). 
function is optimal; in this context, optimal graft function is defined to be serum creatinine $<1.5 \mathrm{mg} / \mathrm{dL}$ with a protein excretion of $<500 \mathrm{mg} / 24$ hours, neither concurrent fetotoxic infections nor the use of teratogenic or fetotoxic medications, and stable immunosuppressive dosing at maintenance levels. ${ }^{7}$ Studies of the effects of pregnancy on renal transplant recipients must focus on maternal graft function and whether pregnancy induces graft-independent comorbidities. In addition, the incidence of complications is influenced by the degree of renal dysfunction, preexisting hypertension, and the extent of proteinuria. ${ }^{8-10}$

The aim of our study was to assess and compare the outcomes of pregnancy in renal transplant patients who inadvertently became pregnant within 24 months of transplantation and renal transplant patients who became pregnant more than 24 months after transplantation.

\section{Materials and methods}

This investigation was a prospective cohort study. The sample population was recruited from patients with unplanned pregnancies following renal transplantation. In all cases, living donors were used for renal transplantation. The study subjects were recruited from multiple centers, including the obstetrics outpatient clinic of Kasr El Ainy Hospital. This study was approved by the Scientific Ethics Committee of Kasr Al Ainy Hospital, Cairo University. All procedures performed in studies involving human participants were conducted in accordance with the ethical standards of the relevant institutional committee and with the 1964 Declaration of Helsinki and its later amendments or comparable ethical standards. Our study sample comprised of 44 patients who agreed to participate and provided written informed consent to their participation in this study. All of the study subjects were in the first trimester of pregnancy, and they participated in an antenatal care program that included the collection of a detailed history, general and obstetric examinations, laboratory investigations, and ultrasonographic examinations. All the patients had serum creatinine $<1.5 \mathrm{mg} / \mathrm{dL}$ and 24 -hour urinary protein $<0.5 \mathrm{~g}$.

The patients were divided into two groups on the basis of the interval between transplantation and pregnancy. For group A, which included 24 patients who became pregnant more than 24 months after renal transplantation, the mean interval was $30.9 \pm 2.3$ months, and the range of intervals was 28-36 months; for group B, which included 20 patients who inadvertently became pregnant within 24 months of renal transplantation, the mean interval was $20.5 \pm 1.9$ months, and the range of intervals was $18-23$ months. All the patients in both groups had been using steroids, cyclosporine, and azathioprine since the discovery of pregnancy, with the exception of 5 patients in group A who did not use azathioprine. These patients followed a routine antenatal care protocol with particular emphasis on the measurements of blood pressure and the degree of proteinuria (based on 24-hour urine protein), which was determined each trimester.

Serum creatinine was measured during each trimester. The incidences of preeclampsia and gestational diabetes were determined.

The timing and the mode of delivery were examined to determine the rate of preterm labor and to compare the rates of the cesarean section and normal vaginal delivery.

The collected fetal information included mean birth weight.

\section{Results}

The demographic characteristics of group A and group B are presented in Table 1 . There were no statistically significant differences between the groups with respect to mean age at pregnancy, mean parity, mean serum creatinine, and mean 24-hour proteinuria during the first trimester. For groups $\mathrm{A}$ and $\mathrm{B}$, the mean gestational ages at time of delivery were $35.8 \pm 3$ weeks and $34.1 \pm 2.5$ weeks, respectively, and the mean fetal birth weights were $2,480 \pm 316 \mathrm{~g}$ and 2,284.5 $\pm 262 \mathrm{~g}$, respectively. These differences were statistically significant.

The incidences of preterm delivery, which was defined to be delivery before 37 weeks, were $45.8 \%$ and $55 \%$ in group A and group B, respectively. Proteinuria was significantly higher in group B during the third trimester.

Table I Baseline characteristics

\begin{tabular}{llll}
\hline $\begin{array}{l}\text { Baseline } \\
\text { characteristics }\end{array}$ & $\begin{array}{l}\text { Group A } \\
(\mathbf{n}=\mathbf{2 4 )}\end{array}$ & $\begin{array}{l}\text { Group B } \\
(\mathbf{n = 2 0 )}\end{array}$ & P-value \\
\hline Maternal age, years & $32.35 \pm 2.34$ & $32.4 \pm 1.9$ & 0.87 \\
Parity & $2.1 \pm 0.63$ & $1.9 \pm 0.76$ & 0.08 \\
$\begin{array}{l}\text { Creatinine before } \\
\text { pregnancy, mg/dL }\end{array}$ & $1.3 \pm 0.18$ & $1.29 \pm 1.6$ & 0.97 \\
$\begin{array}{l}\text { Protenuria before } \\
\text { pregnancy, g/24 hours }\end{array}$ & $0.4 \pm 0.1$ & $0.44 \pm 0.1$ & 0.19 \\
$\begin{array}{l}\text { Primary disease, \% } \\
\quad \text { Glomerulonephritis }\end{array}$ & 62.5 & & \\
$\quad$ Reflux & 16.6 & 20 & 0.8 \\
$\quad \begin{array}{l}\text { Undetermined } \\
\text { Range of dialysis time before } \\
\text { transplantation, months }\end{array}$ & 20.8 & 20 & 0.8 \\
\hline Notes: Group A, pan & & & \\
\hline
\end{tabular}

Notes: Group A, patients who became pregnant more than 24 months after renal transplantation; Group B, patients who inadvertently became pregnant within 24 months of renal transplantation. 
Table 2 Maternal and neonatal outcomes

\begin{tabular}{llll}
\hline $\begin{array}{l}\text { Maternal and neonatal } \\
\text { outcome }\end{array}$ & Group A & Group B & P-value \\
\hline $\begin{array}{l}\text { Mean creatinine (mg/dL) } \\
\quad \text { Ist trimester }\end{array}$ & $1.2 \pm 0.12$ & $1.15 \pm 0.09$ & 0.13 \\
$\quad$ 2nd trimester & $1.31 \pm 0.16$ & $1.39 \pm 0.18$ & 0.12 \\
$\quad$ 3rd trimester & $1.42 \pm 0.24$ & $1.46 \pm 0.27$ & 0.6 \\
Mean protenuria (g/24 hours) & & & \\
$\quad$ Ist trimester & $0.47 \pm 0.21$ & $0.54 \pm 0.2$ & 0.26 \\
2nd trimester & $0.6 \pm 0.25$ & $0.77 \pm 0.37$ & 0.08 \\
3rd trimester & $0.72 \pm 0.32$ & $0.97 \pm 0.43$ & 0.03 \\
Gestational age at delivery, days & $251.2 \pm 21.2$ & $239 \pm 17.2$ & 0.04 \\
Fetal birth weight, g & $2,480.9 \pm 316$ & $2,282.5 \pm 262.5$ & 0.033 \\
Preeclampsia, \% & 25 & 30 & 0.95 \\
Gestational diabetes, \% & 8.3 & 10 & 0.85 \\
Preterm deliveries, \% & 45.5 & 50 & 0.78 \\
Normal vaginal delivery, \% & 58.3 & 55 & 0.82 \\
Cesarean section, \% & 41.6 & 45 & 0.82 \\
\hline Notes: GroupA,
\end{tabular}

Notes: Group A, patients who became pregnant more than 24 months after renal transplantation; Group B, patients who inadvertently became pregnant within 24 months of renal transplantation.

Preeclampsia occurred in $25 \%$ of the patients in group A (6 out of 24 ) and $30 \%$ of the patients in group B (6 out of 20 ), although this difference was not statistically significant. Gestational diabetes occurred in 2 out of 24 patients in group A and in 2 out of 20 patients in group B. None of the pregnancies ended in abortion. For group $\mathrm{A}$ and group B, normal vaginal delivery occurred in $58.3 \%$ and $55 \%$ of patients, respectively, whereas a cesarean section was performed in $41.6 \%$ and $45 \%$ of patients, respectively. Only 1 of the 24 patients in group A exhibited postpartum hemorrhage, and this hemorrhage was controlled using ecbolics. Cesarean section wound infection occurred in 2 out of the 24 patients in group A and in 3 out of the 20 patients in group B (Tables 2-4).

\section{Discussion}

In our study, we compared the outcomes of pregnancy after renal transplantation for two groups of patients: group A, which included 24 patients who became pregnant more than 2 years after renal transplantation, and group B, which

Table 3 Changes in the mean serum creatinine and mean protenuria 6 months postpartum

\begin{tabular}{lcll}
\hline & Group A & Group B & P-value \\
\hline $\begin{array}{l}\text { Mean creatinine }(\mathrm{mg} / \mathrm{dL}) \\
6 \text { months postpartum }\end{array}$ & $1.36 \pm 0.218$ & $1.4 \pm 0.27$ & 0.61 \\
$\begin{array}{l}\text { Mean protenuria (g/24 hours) } \\
6 \text { months postpartum }\end{array}$ & $0.41 \pm 0.18$ & $0.44 \pm 0.09$ & 0.6 \\
\hline
\end{tabular}

Notes: Group A, patients who became pregnant more than 24 months after renal transplantation; Group B, patients who inadvertently became pregnant within 24 months of renal transplantation.
Table 4 Apgar score at I, 5, and 10 minutes after delivery

\begin{tabular}{llll}
\hline Apgar score & Group A & Group B & P-value \\
\hline I minute & $6.54 \pm 0.88$ & $6.50 \pm 0.61$ & 0.8592 \\
5 minutes & $7.42 \pm 0.78$ & $7.50 \pm 0.61$ & 0.6979 \\
I0 minutes & $8.38 \pm 1.28$ & $8.15 \pm 0.88$ & 0.5086 \\
\hline
\end{tabular}

Notes: Group A, patients who became pregnant more than 24 months after renal transplantation; Group B, patients who inadvertently became pregnant within 24 months of renal transplantation.

included 20 patients who became pregnant within 2 years of renal transplantation. We found significantly better outcomes in group A than in group B with respect to gestational age at time of delivery ( $35.8 \pm 3$ weeks versus $34.1 \pm 2.5$ weeks) and fetal birth weight $(2,480.9 \pm 316 \mathrm{~g}$ versus $2,282.5 \pm 262.5 \mathrm{~g})$. The incidences of preterm delivery were $45.8 \%$ and $55 \%$ for group A and group B, respectively, although this difference was not statistically significant. In $2016, \mathrm{Li}$ et a ${ }^{11}$ assessed 15 pregnancies in 13 women who had undergone renal transplantation; the mean interval between transplantation and pregnancy was 4 years and 6 months. Their findings were comparable to those of our study. In particular, in their study, the mean gestational age was $35.4 \pm 3$ weeks (range, 26.1-38.3 weeks), the mean birth body weight was 2,208.8 $\pm 678.8 \mathrm{~g}$ (range, 524-3,308 g), and the incidence of preterm delivery was $53.3 \%$.

In 2016, Stoumpos et al ${ }^{12}$ studied 138 pregnancies in 89 women who had undergone renal transplantation from 1973 to 2013. In that study, the median interval between transplantation and pregnancy was 3 years and 6 months, the median gestational age was $34 \pm 3$ weeks, and the mean birth body weight was $2,464 \mathrm{~g}$; however, there was a high prevalence of prematurity (61\%).

However, in 2016, El Houssni et a ${ }^{13}$ found much better outcomes of pregnancy after renal transplantation. That study included 21 pregnancies in 12 women who had undergone renal transplantation, with a mean interval between transplantation and pregnancy of 3 years and 6 months; 7 pregnancies had occurred within 2 years of transplantation. The mean gestational age was $37 \pm 2$ weeks. The mean birth body weight was $3,014 \pm 515.8 \mathrm{~g}$, and the incidence of prematurity was only $19 \%$.

In our study, maternal complications included preeclampsia of pregnancy, which had incidences of $25 \%$ (6 out of 24 patients) in group A and 30\% (6 out of 20 patients) in group B, although this difference was not statistically significant. However, mean 24-hour proteinuria during the third trimester was significantly higher in group B than in group A. The incidences of gestational diabetes were 8.3\% $(\mathrm{n}=2)$ in group $\mathrm{A}$ and $10 \%(\mathrm{n}=2)$ in group $\mathrm{B}$. Li et al ${ }^{11}$ reported 
a prevalence of preeclampsia of pregnancy of $26.7 \%$, a gestational diabetes rate of $13.3 \%$, and no maternal mortality during pregnancy or delivery. However, in 2016, Stoumpos et $\mathrm{al}^{12}$ found a much lower incidence of preeclampsia (14\%), whereas in 2014 , You et $\mathrm{al}^{14}$ reported a much higher prevalence of preeclampsia (36.7\%). You et $\mathrm{al}^{14}$ reviewed potential predictive factors for pregnancy outcomes, including transplantation-pregnancy interval. They concluded that prepregnancy serum creatinine level was the most powerful predictor of pregnancy outcomes.

\section{Conclusion}

In conclusion, an interval of at least 24 months between transplantation and pregnancy was associated with significantly better outcomes with respect to gestational age at time of delivery, fetal gestational weight, and proteinuria during the third trimester. Although the maternal complications of preeclampsia and gestational diabetes were less prevalent among women with a transplantation-pregnancy interval of at least 24 months, these differences were not significant.

\section{Disclosure}

The authors report no conflicts of interest in this work.

\section{References}

1. Nevis IF, Reitsma A, Dominic A, et al. Pregnancy outcomes in women with chronic kidney disease: a systematic review. Clin J Am Soc Nephrol. 2011;6: 2587-2598.
2. Deshpande NA, James NT, Kucirka LM, et al. Pregnancy outcomes in kidney transplant recipients: a systematic review and meta-analysis. Am J Transplant. 2011;11:2388-2404.

3. Murray JE, Reid DE, Harrison JH, et al. Successful pregnancies after human renal transplantation. N Engl J Med. 1963;269:346.

4. Davison JM. Pregnancy in renal allograft recipients: prognosis and management. Ballier Clin Obstet Gynecol. 1987;1:1027-1045.

5. McKay DB, Josephson MA. Reproduction and transplantation: report on the AST consensus conference on reproductive issues and transplantation. Am J Transplant. 2005;5:1592-1599.

6. Kasiske BL, Zeier MG, Craig JC, et al. Kdigo clinical practice guideline for the care of kidney transplant recipients. Sexual and fertility: Female fertility. Am J Transplant. 2009;9(Supp1 3):S106-S109.

7. Fischer MJ, Lehnerz SD, Hebert JR, Parikh CR. Kidney disease is an independent risk factor for adverse fetal and maternal outcomes in pregnancy. Am J Kidney Dis. 2004;43:415-423.

8. Fischer MJ. Chronic kidney disease and pregnancy: Maternal and fetal outcomes. Adv Chronic Kidney Dis. 2007;14:132-145.

9. Thomas AG, Burrows L, Knight R, Panico M, Lapinski R, Lockwood CJ. The effect of pregnancy on cyclosporine levels in renal allograft patients. Obstet Gynecol. 1997;90:916-919.

10. McKay DB, Josephson MA. Pregnancy in recipients of solid organs: Effects on mother and child. N Engl J Med. 2006;354:1281-1293.

11. Li YP, Shih JC, Lin SY, Lee CN. Pregnancy outcomes after kidney transplantation-A single-center experience in Taiwan. Taiwan J Obstet Gynecol. 2016;55:314-318.

12. Stoumpos S, McNeill SH, Gorrie M, et al. Obstetric and long-term kidney outcomes in renal transplant recipients: a 40-yr single-center study. Clin Transplant. 2016;30:673-681.

13. El Houssni S, Sabri S, Benamar L, Ouzeddoun N, Bayahia R, Rhou H. Pregnancy after renal transplantation: effects on mother, child, and renal graft function. Saudi J Kidney Dis Transpl. 2016;27(2): 227-232.

14. You JY, Kim MK, Choi SJ, et al. Predictive factors for adverse pregnancy outcomes after renal transplantation. Clin Transplant. 2014;28(6): 699-706.
International Journal of Women's Health

\section{Publish your work in this journal}

The International Journal of Women's Health is an international, peerreviewed open-access journal publishing original research, reports, editorials, reviews and commentaries on all aspects of women's healthcare including gynecology, obstetrics, and breast cancer. The manuscript management system is completely online and includes

\section{Dovepress}

a very quick and fair peer-review system, which is all easy to use. Visit http://www.dovepress.com/testimonials.php to read real quotes from published authors. 